\title{
PERANAN DISIPLIN KERJA DAN LINGKUNGAN KERJA DALAM KINERJA KARYAWAN DEPARTEMEN MOLDING PT FCC INDONESIA
}

\author{
Imam Sucipto ${ }^{1}$ \\ Ahmad Gunawan ${ }^{2}$ \\ ${ }^{1}$ Fakultas Ekonomi Bisnis dan Ilmu Sosial, Universitas Pelita Bangsa \\ Email : imamsucipto64@yahoo.com \\ ${ }^{2}$ Fakultas Ekonomi Bisnis dan Ilmu Sosial, Universitas Pelita Bangsa \\ Email : ahmadgunawan@pelitabangsa.ac.id
}

\begin{abstract}
Abstrak
Permasalahan yang dihadapi oleh PT FCC Indonesia adalah rendahnya kinerja karyawannya. Disiplin kerja dan lingkungan kerja diduga sebagai faktor yang memengaruhi kinerja karyawan. Tujuan peneltian ini adalah untuk mengetahui apakah ada pengaruh disiplin kerja dan lingkungan kerja terhadap kinerja karyawan Departemen Molding PT FCC Indonesia. Jenis penelitian ini adalah penelitian kuantitatif. Data yang digunakan adalah data primer dan data sekunder. Data primer yang peneliti gunakan berasal dari kuesioner yang diberikan kepada responden dan dari wawancara. Sedangkan data sekundernya berasal dari sumber-sumber lain. Populasi dalam penelitan ini adalah karyawan Departemen Molding PT FCC Indonesia yang berjumlah 120 orang. Jumlah karyawan yang menjadi sampel adalah 93 orang ditentukan dengan menggunakan rumus Slovin. Pengambilan sampel dengan menggunakan simple random sampling. Teknik Pengumpulan data dilakukan dengan wawancara, kuesioner, dan studi pustaka. Metode analisis data yang digunakan adalah regresi linear berganda. Hasil yang diperoleh setelah peneliti melakukan pengujian adalah secara parsial disiplin kerja dan lingkungan kerja berpengaruh positif tehadap kineja karyawan yang ditunjukkan dengan angka hasil penghitungan yang positif. Secara simultan, disiplin kerja dan lingkungan kerja juga berpengaruh terhadap kinerja karyawan.
\end{abstract}

Kata kunci: Disiplin Kerja, Lingkungan Kerja, Kinerja Karyawan

\section{PENDAHULUAN}

Di semua organisasi sumber daya manusia adalah harta yang paling penting. Tujuan organisasi tidak mungkin dapat dicapai jika organisasi mengabaikan keberadaan sumber daya manusia karena sumber daya ini merupakan satu satunya sumber daya yang yang memiliki akal, perasaan, keinginan, kemampuan, keterampilan, pengetahuan, dorongan, daya dan karya. Kecanggihan teknologi, perkembangan informasi yang pesat, ketersediakaan modal, dan bahan-bahan yang memadai tidak akan dapat mencapai tujuan perusahaan tanpa didukung sumber daya manusia yang yang potensial (Hamali, 2018: 3).

Di tengah persaingan yang semakin ketat, perusahan harus dapat bertahan dan memenangkan persaingan. Untuk itu perusahaan harus mencari keunggulan bersaing melalui kinerja pegawainya. Kinerja yang baik secara individu sangat penting untuk membantu perusahaan mencapai tujuan perusahaan. Tanpa adanya kinerja individu yang baik tidak akan tercapai kinerja perusahaan yang baik. Untuk mencapai tujuan perusahaan, para karyawan harus memiliki kinerja yang baik. Kinerja individu dapat dilihat dari apakah sorang pegawai dapat mengerjakan sesuatu dengan keahlian tertentu. Jadi kinerja seorang pegawai sangatlah perlu diketahui karena dengan kinerja dapat diketahui seberapa jauh kemampuan pegawai dalam melakukan sesuatu (Sinambela, 2018: 480).

Pegawai yang dapat mengerjakan sesuatu sesuai dengan keahlian tertentu dikatakan mempunyai kinerja yang baik yang akan membuat kinerja pimpinan juga menjadi baik dan pada akhirnya akan membuat kinerja perusahaan akan menjadi baik sehingga tujuan perusahaan akan dapat dicapai. Meskipun demikian, kinerja pegawai akan tetap rendah meskipun pegawai itu sebenarnya mempunyai kemampuan dan ketrampilan karena ada faktor lain yang tidak dimasukkan, yaitu disiplin kerja. Tanpa dukungan disiplin kerja yang baik, sulit bagi perusahaan untuk mencapai tujuannya (Sinambela, 2018: 335). 
Tujuan perusahaan akan mudah dicapai jika para karyawan dapat bekerja sama karena tujuan perusahaan tidak bisa dicapai oleh karyawan yang bekerja secara individu. Karyawan yang disiplin akan secara sukarela berusaha bekerja secara kooperatif dengan karyawan yang lain serta meningkatkan prestasi kerjanya (Siagian, 2018: 305), selain disiplin kerja, lingkungan kerja juga dapat memengaruhi kinerja karyawan. Lingkungan kerja yang baik dapat mendorong semangat dan kegairahan karyawan dalam bekerja (Nitisemito, 2018: 183).

PT. FCC Indonesia adalah sebuah perusahaan yang berpusat di Osaka, Jepang. Perusahaan ini bergerak di bidang manufaktur khususnya untuk kebutuhan kendaraan roda dua dan roda empat, yaitu produk clutch coopling. Masalah yang dihadapi oleh perusahaan ini adalah menurunnya kinerja karyawan sepanjang tahun 2017, 2018, dan 2019. Ini dapat diketahui dari hasil wawancara yang dilakukan dengan pihak pimpinan Departemen Molding.

Indikasi penurunan kinerja karyawan ini ditunjukkan dengan laporan ketidakhadiran karyawan sepanjang tahun 2017, 2018, dan 2019. Tabel 1 di bawah ini menunjukkan ketidakhadiran karyawan.

Tabel 1.

Data Ketidakhadiran Karyawan

\begin{tabular}{cccc}
\hline Ketidakhadiran & 2017 & 2018 & 2019 \\
\hline Sakit & 57 & 59 & 64 \\
\hline Izin & 35 & 42 & 55 \\
\hline Alfa & 24 & 26 & 35 \\
\hline Total & 116 & 127 & 154
\end{tabular}

Sumber: Admin Departemen Molding PT FCC Indonesia

Dari tabel di atas, dapat diketahui kenaikan jumlah karyawan yang tidak hadir pada tahun 2017 ke tahun 2018 mengalami kenaikan. Untuk karyawan yang sakit mengalami kenaikan 3,50\%. Karyawan yang izin mengalami kenaikan $20 \%$. Karyawan yang alfa mengalami kenaikan 8,33\%. Secara keseluruhan jumlah karyawan yang tidak hadir mengalami kenaikan 9,48\%. Dari tabel itu juga dapat diketahui kenaikan jumlah karyawan yang tidak hadir dari tahun 2018 ke tahun 2019. Untuk karyawan yang sakit mengalami kenaikan $8,47 \%$. Karyawan yang izin mengalami kenaikan 30,95\%. Karyawan yang alfa mengalami kenaikan $34,61 \%$. Secara keseluruhan jumlah karywan yang tidak hadir mengalami kenaikan $21,25 \%$.

Selain disiplin kerja dan linkungan kerja yang dapat memengaruhi kinerja karyawan, masih ada faktor-faktor lain yang dapat memengaruhi kinerja karyawan yaitu faktor kondisi fisik, peralatan, waktu, material, pendidikan, supervisi, desain organisasi, pelatihan, dan keberuntungan (Byar dan Rue dalam Sutrisno, 2017: 151-152).

Dalam penelitian ini, peneliti membatasi penelitiannya hanya pada pengaruh disiplin kerja dan lingkungan kerja terhadap kinerja karyawan Departemen Molding PT FCC Indonesia. Ini dilakukan agar penelitian ini lebih terarah dan fokus. Peneliti tertarik melakukan penelitian dengan judul "Peranan Displin Kerja dan Lingkungan Kerja dalam Kinerja Karyawan Departemen Molding PT FCC Indonesia". Peneliti tertarik karena masalah kinerja karyawan sangat penting bagi perusahaan.

Berdasarkan pada apa yang telah diuraikan di atas, maka peneliti dapat merumukan masalah penelitiannya seperti berikut:

1. Apakah disiplin kerja berpengaruh terhadap kinerja karyawan Departemen Molding PT FCC Indonesia?

2. Apakah lingkungan kerja berpengaruh terhadap kinerja karyawan Departemen Molding PT FCC Indonesia?

3. Apakah disiplin kerja dan lingkungan kerja secara simultan berpengaruh terhadap kinerja karyawan Departemen Molding PT FCC Indonesia?

Dari rumusan di atas dapat diutarakan tujuan dari penelitian ini, yaitu:

1. Untuk mengetahui pengaruh disiplin kerja terhadap kinerja karyawan Departemen Molding PT FCC Indonesia.

2. Untuk mengetahui pengaruh lingkungan kerja terhadap kinerja karyawan Departemen Molding PT FCC Indonesia.

3. Untuk mengetahui pengaruh disiplin kerja kerja dan lingkungan kerja secara simultan terhadap karyawan Departemen Molding PT FCC Indonesia. 


\section{KAJIAN PUSTAKA}

Kinerja Karyawan

Mangkunegara (2017: 67) mendefinisikan kinerja yang berasal dari kata Job Performance atau Actual Performance sebagai hasil kerja secara kualitas dan kuantitas yang dicapai oleh seorang pegawai dalam melaksanakan tugasnya sesuai dengan tanggung jawab yang diberikan kepadanya. Definisi lain dari kinerja diberikan oleh Hariandja (dalam Tanujaya, 2015), kinerja adalah unjuk kerja yang merupakan hasil kerja dihasilkan oleh pegawai atau perilaku nyata yang ditampilkan sesuai dengan perannya dalam organisasi. Menurut Hasibuan (2009: 94), prestasi kerja adalah suatu hasil kerja yang dicapai seseorang dalam melaksanakan tugas-tugas yang dibebankan kepadanya yang didasarkan atas kecakapan, pengalaman, dan kesungguhan serta waktu. Sedangkan menurut Khan at al. (dalam Busro, 2020:87), kinerja adalah kemampuan kerja di dalam terminologi kualitas dan kuantitas. Menurut Hasibuan (dalam Busro, 2020: 94) ada beberapa faktor yang memengaruhi kinerja karyawan, yaitu:

1. Kemampuan melaksanakan pekerjaan

2. Minat bekerja

3. Kejelasan delegasi tugas dan peran

4. Tingkat motivasi kerja

Bernardin dan Russel (dalam Busro, 2020: 96) menyatakan bahwa ada enam kriteria untuk menilai kinerja karyawan, yaitu:

1. Quality, yaitu tingkatan di mana proses atau penyesuain pada cara yang ideal di dalam melakukan aktivitas.

2. Quantity, yaitu jumlah yang dihasilkan diwujudkan melalui nilai mata uang, jumlah unit, atau jumlah dari siklus aktivitas yang telah diselesikan.

3. Timelines, yaitu tingkatan di mana aktivitas telah diselesaikan dengan waktu yang lebih cepat dari yang ditentukan dan memaksimalkan waktu yang ada untuk aktivitas lain.

4. Cost effectiveness, yaitu tingkatan di mana penggunaan sumber daya perusahaan berupa manusia, keuangan, dan teknologi dimaksimalkan untuk mendapatkan hasil yang tertinggi atau pengurangan kerugian dari tiap unit.

5. Need for supervision, yaitu tingkatan di mana seorang karyawan dapat melakukan pekerjaannya tanpa perlu meminta pertolongan atau bimbingan dari atasannya.

6. Interpersonal impact, yaitu tingkatan yang menunjukkan seorang karyawan merasa percaya diri, punya keinginan yang baik, dan bekerja sama di antara rekan kerja.

\section{Disiplin Kerja}

Menurut Siagian (2018: 305), disiplin kerja adalah tindakan manajemen untuk mendorong para anggota organisasi memenuhi tuntutan berbagai ketentuan, sedangkan menurut Handoko (dalam Hamali, 2018: 213), disiplin kerja merupakan kegiatan manajemen untuk menjalankan standar-standar organisasional. Hasibuan (dalam Sinambela, 2018: 356) menyatakan bahwa ada beberapa faktor yang memengaruhi tingkat kedisiplinan kerja seorang karyawan, yaitu:

1. Tujuan dan kemampuan

2. Teladan pimpinan

3. Balas jasa

4. Keadilan

5. Waskat (pengawasan melekat)

6. Sanksi hukuman

7. Ketegasan

8. Hubungan kemanusian

Menurut Siswanto (dalam Sinambela, 2018: 356) ada lima indikator disiplin kerja, yaitu:

1. Frekuensi kehadiran. Salah satu tolok ukur untuk mengetahui tingkat kedisiplinan pegawai adalah semakin tinggi frekuensi kehadirannya atau rendahnya tingkat kemangkiran maka pegawai itu tersebut telah memiliki disiplin kerja yang tinggi.

2. Tingkat kewaspadaan. Pegawai yang dalam melaksanaan pekerjaannya selalu penuh perhitungan dan ketelitian memiliki tingkat kewaspadaan yang tinggi baik terhadap dirinya maupun terhadap pekerjaannya. 
3. Ketaatan pada standar kerja. Dalam melaksanakan pekerjaannya, seorang pegawai diharuskan menaati semua standar kerja yang telah ditetapkan sesuai dengan aturan dan pedoman kerja agar kecelakaan kerja tidak terjadi atau dapat dihindari.

4. Ketaatan pada peraturan kerja. Hal ini dimaksudkan untuk kenyamanan dalam bekerja.

5. Etika kerja. Etika kerja diperlukan oleh setiap pegawai dalam melaksanakan pekerjaannya agar tercipta suasana harmonis, saling menghargai antarsesama pegawai.

\section{Lingkungan Kerja}

Menurut Robbins (dalam Liestiani et al., 2019), lingkungan adalah institusi-institusi atau kekuatan-kekuatan yang secara potensial memengaruhi kinerja organisasi. Ahyari (dalam Sarwani, 2016) mendefinisikan bahwa lingkungan kerja sebagai sebuah lingkungan di mana para pegawai melakukan tugas-tugas dan pekerjaan sehari-hari. Definisi lain diberikan oleh Sutrisno (dalam Farisi dan Fani, 2019) bahwa lingkungan kerja dapat berarti keseluruhan infrastruktur di sekitar pekerjaan karyawan yang ada.

Sedarmayanti (dalam Polakitan et al., 2016) menyatakan bahwa terdapat beberapa faktor yang memengaruhi suatu kondisi lingkungan kerja, yaitu:

1. Penerangan/ cahaya di tempat kerja. Cahaya atau penerangan sangatlah basar manfaatnya bagi karyawan guna mendapat keselamatan dan kelancaran kerja.

2. Temperatur / suhu udara di tempat kerja. Dalam keadaan normal, tiap anggota suhu manusia mempunyai suhu berbeda, tubuh manusia selalu berusaha untuk mempertahankan keadaan normal, dengan suatu sistem tubuh yang sempurna sehingga dapat menyesuaikan diri dengan perubahan yang terjadi di luar tubuh.

3. Kelembaban di tempat kerja. Kelembaban adalah banyaknya air yang terkandung dalam udara, biasa dinyatakan dalam persentase. Kelembaban ini berhubungan atau dipengaruhi oleh temperatur udara, dan secara bersama-sama antara temperatur, kelembaban, kecepatan udara bergerak dan radiasi panas dari udara tersebut akan memengaruhi keadaan tubuh manusia pada saat menerima atau melepaskan panas dari tubuhnya.

4. Sirkulasi udara di tempat kerja. Oksigen merupakan gas yang dibutuhkan makhluk hidup untuk menjaga kelangsungan hidup, yaitu untuk proses metabolisme. Udara di sekitar dikatakan kotor apabila kadar oksigen, dalam udara tersebut telah berkurang dan telah bercampur dengan gas atau bau-bauan yang yang berbahaya bagi bagi kesehatan tubuh. Sumber utama dari dari adanya udara segar adalah tanaman disekitar tempat kerja.

5. Kebisingan di tempat kerja. Salah satu polusi untuk menyibukkan para pakar untuk mengatasinya adalah kebisingan. Yaitu bunyi yang tidak dikehendaki oleh telinga. Tidak dikehendaki, karena terutama dalam jangka panjang bunyi tersebut dapat mengganggu ketenangan kerja, merusak pendengaran, dan menimbulkan kesalahan komunikasi.

6. Getaran mekanis di tempat kerja. Getaran mekanis dapat mengganggu konsentrasi kerja, mengakibatkan kelelahan dan timbul beberapa penyakit, seperti penyakit mata, syaraf, peredaran darah, otot, tulang, dan lain-lain.

7. Bau-bauan di tempat kerja. Adanya bau-bauan di tempat kerja dapat dianggap sebagai pencemaran, karena dapat mengganggu konsentrasi bekerja, dan bau-bauan yang terjadi secara terus menerus dapat memengaruhi kepekaan penciuman.

8. Tata warna di tempat kerja. Sifat dan pengaruh warna kadang-kadang menimbulkan rasa senang, sedih, dan lain-lain. Karena dalam sifat warna dapat merangsang perasaan manusia.

9. Dekorasi di tempat kerja. Dekorasi ada hubungannya dengan tata warna yang baik, karena itu dekorasi tidak hanya berkaitan dengan hasil ruang kerja saja tetapi berkaitan juga cara mengatur tata letak, tata warna, perlengkapan, dan lainnya untuk bekerja.

10.Musik di tempat kerja. Menurut para pakar, musik yang nadanya lembut sesusi dengan suasana, waktu dan tempat dapat membangkitkan dan merangsang karyawan untuk bekerja.

11.Keamanan di tempat kerja. Guna menjaga tempat dan kondisi lingkungan kerja tetap dalam keadaan aman maka perlu diperhatikan keberadaannya. Salah satunya untuk menjaga keamanan di tempat kerja, dapat dimanfaatkan tenaga Satuan Petugas Keamanan (SATPAM). 


\section{Gambar 1. Model Penelitian}

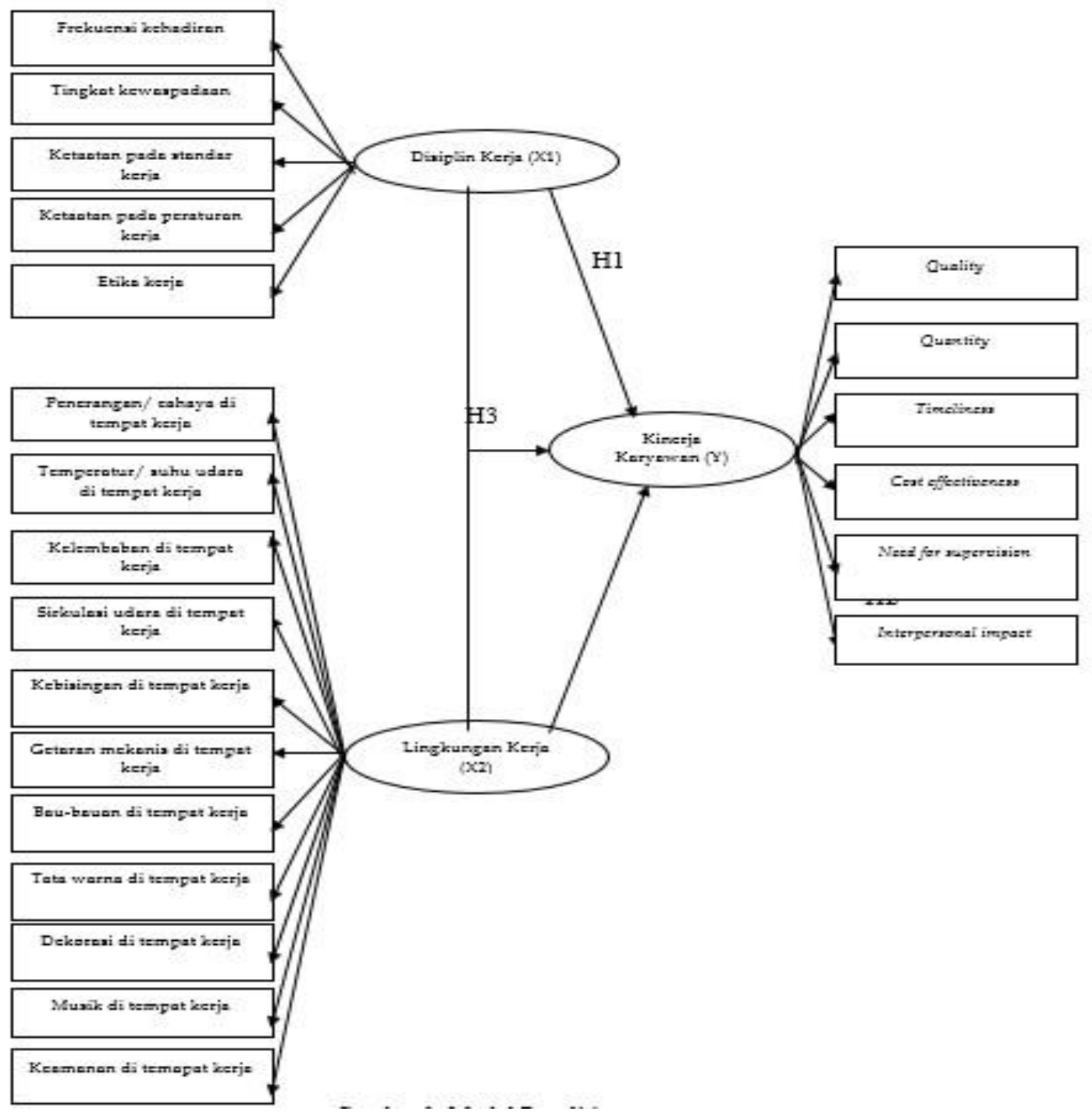

Sumber: Variabel Kinerja Karyawan dari Bernardin dan Russel (dalam Busro, 2020: 96), Variabel Disiplin Kerja dari Bejo (dalam Sinambela, 2018: 356), dan Variabel Lingkungan Kerja dari Sedarmayanti (dalam jurnal Polakitan at al., 2016).

Mengacu pada model penelitian di atas dan berdasarkan rumusan masalah yang diutarakan pada bagian pendahuluan, hipotesis dalam penelitian ini dapat dibuat sebagai berikut:

\section{H1: Ada pengaruh disiplin kerja terhadap kinerja karyawan Departemen Molding PT FCC} Indonesia.

Ini sesuai dengan hasil penelitian yang dilakukan oleh Sarwani. Artikel peneliti yang berjudul The Effect of Work Discipline and Work Environment on The Performance of Employees terbit di jurnal Sinergi Vol. 6 No. 2, September 2016. Dalam artikel tersebut, peneliti menyimpulkan bahwa disiplin kerja berpengaruh terhadap kinerja karyawan.

\section{H2: Ada pengaruh lingkungan kerja terhadap kinerja karyawan Departemen Molding PT FCC Indonesia.}

Hipotesis ini sesuai dengan hasil penelitian yang dilakukan oleh Handayani. Artikel peneliti yang yang berjudul Effect of Discipline and Work Environment on Employee Performance in Ciputat Sector Police terbit di jurnal Pinisi Discretion Review Vol. 2 No. 2, Maret 2019. Dalam artikel tersebut peneliti menyimpulkan bahwa lingkungan kerja berpengaruh terhadap kinerja karyawan. 
H3: Ada pengaruh disiplin kerja dan lingkungan kerja secara simultan terhadap kinerja karyawan Departemen Molding PT FCC Indonesia.

Hipotesis ini sesuai dengan hasil penelitian yang dilakukan oleh Ferawati. Artikel peneliti yang berjudul Pengaruh Lingkungan Kerja dan Disiplin Kerja terhadap Kinerja Karyawan terbit di jurnal AGORA Vol. 5 No. 1, 2017. Dalam artikel itu peneliti menyimpulkan bahwa disiplin kerja dan lingkungan kerja berpengaruh secara simultan terhadap kinerja karyawan.

\section{METODOLOGI}

Penelitian ini dilakukan di Departemen Molding PT FCC Indonesia. Ini dilaksanakan dari bulan Maret 2021 sampai bulan April 2021. Penelitian ini adalah penelitian kuantitatif. Peneliti membuat hipotesis dan kemudian melakukan pengujian untuk menerima atau menolak hipotesis itu; yaitu, pengaruh disiplin kerja (X1) dan lingkungan kerja (X 2) terhadap kinerja karyawan (Y) baik secara parsial maupun secara simultan.

Data yang digunakan dalam penelitian adalah data primer dan data sekunder. Data primer yang digunakan dalam penelitian ini adalah data yang diperoleh dari responden dengan menggunakan kuesioner dan data dari hasil wawancara. Sedangkan data sekunder diperoleh dari sumber- sumber lain. Populasi dalam penelitian ini adalah karyawan Departemen Molding PT FCC Indonesia yang berjumlah 120 orang. Dengan menggunakan rumus Slovin diperoleh sampel dengan jumlah 93 orang. Proses pengambilan sampel dengan menggunakan simple random sampling. Kuesioner yang digunakan untuk mengumpulkan data berisi pernyataan-pernyataan untuk memperoleh respon dengan menggunakan skala Likert dimana skor 1 sangat tidak setuju, skor 2 tidak setuju, skor 3 netral, skor 4 setuju, dan skor 5 sangat setuju. Metode analisis data yang digunakan untuk mengetahui pengaruh disiplin kerja dan lingkungan kerja terhadap kinerja karyawan baik secara parsial maupun simultan adalah regresi linear berganda.

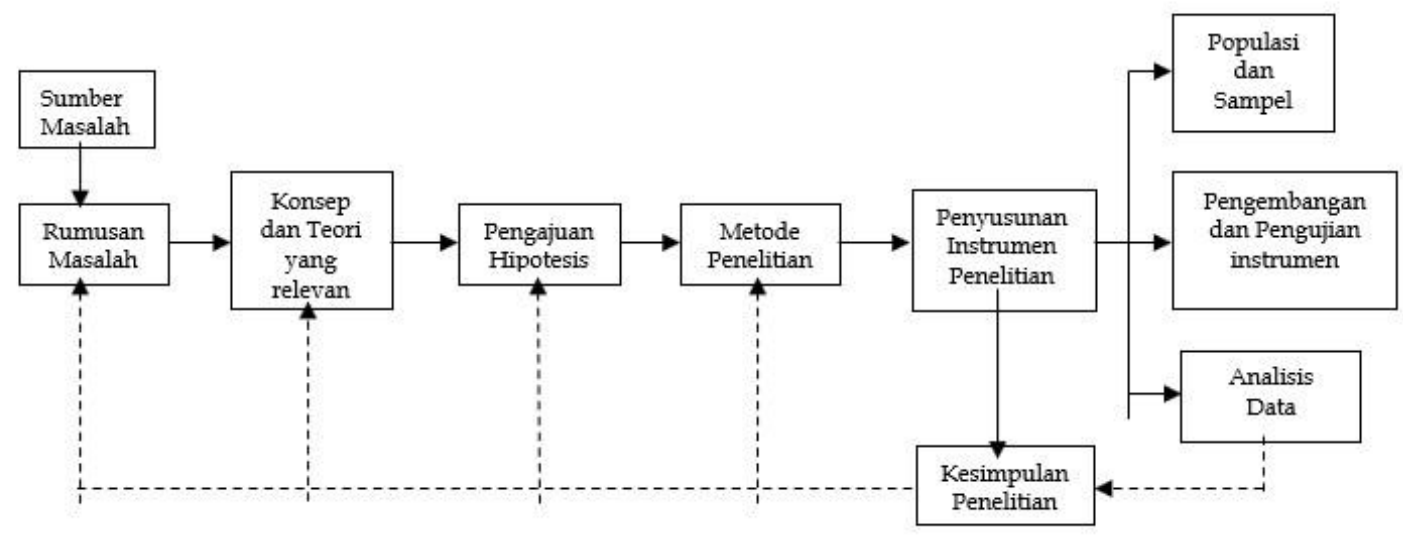

Gambar 2. Desain Penelitian

\section{HASIL PENELITIAN}

Karakteristik responden dalam penelitian ini dapat dilihat pada tabel di bawah ini.

Tabel 2.

Karakteristik Responden Berdasarkan Jenis Kelamin

\begin{tabular}{ccc}
\hline Jenis Kelamin & Frekuensi & Persen \\
\hline Laki-Laki & 83 & $89,25 \%$ \\
Perempuan & 10 & $10,75 \%$ \\
Jumlah & 93 & $100 \%$ \\
\hline
\end{tabular}

Sumber: Bagian Personalia PT FCC Indonesia

Dari tabel 2 di atas, dapat diketahui bahwa mayoritas karyawan berjenis kelamin laki-laki $89,25 \%$. Sedangkan karyawan yang berjenis kelamin perempuan sebanyak $10,75 \%$. 
Tabel 3.

Karakteristik Responden Berdasarkan Usia

\begin{tabular}{ccc}
\hline Usia & Jumlah & Persentase \\
\hline$<20$ tahun & 25 & $26,88 \%$ \\
\hline $20-29$ tahun & 48 & $51,61 \%$ \\
\hline $30-39$ tahun & 20 & $21,51 \%$ \\
\hline$>40$ tahun & 0 & $0 \%$ \\
\hline Total & 93 & $100 \%$ \\
\hline
\end{tabular}

Sumber: Bagian Personalia PT FCC Indonesia

Dari tabel 3, dapat diketahui bahwa mayoritas karyawan berusia 20 - 29 tahun dengan 51,61\%. Karyawan terbanyak kedua adalah kartawan yang berusia $<20$ tahun dengan $26,88 \%$. Karyawan yang berusia lebih 30-39 tahun sebanyak 21,51\%. Tidak ada karyawan yang berusia $>40$ tahun.

Tabel 4.

Karakteristik Responden Berdasarkan Pendidikan Terakhir

\begin{tabular}{ccc}
$\begin{array}{c}\text { Pendidikan } \\
\text { Terakhir }\end{array}$ & Jumlah & Persentase \\
\hline SMA/ Sederajat & 90 & $96,77 \%$ \\
\hline D3 & 0 & $0 \%$ \\
\hline S1 & 3 & $3,23 \%$ \\
S2 & 0 & $0 \%$ \\
S3 & 0 & $0 \%$ \\
\hline Total & 93 & $100 \%$
\end{tabular}

Sumber: Bagian Personalia PT FCC Indonesia

Dari tabel 4, dapat diketahui bahwa sebagian besar karyawan berpendidikan SMA/ Sederajat dengan 96,77\%. Pada urutan kedua adalah karyawan berpendidikan S1 dengan 3,23\%. Tidak ada karyawan yang berpendidikan D3, S2, atau S3.

\section{Uji Instrumen}

Uji Validitas

Dalam penelitian ini uji validitas dilakukan dengan menggunakan Pearson Product Moment. Sebuah alat ukur dinyatakan valid jika $r$ hitung lebih besar daripada $r$ tabel. Atau nilai signifikansi lebih kecil daripada 0,05 .

Variabel Disiplin Kerja (X1)

\begin{tabular}{lccl} 
& \multicolumn{2}{c}{ Tabel 5. Uji Validitas Disiplin kerja } \\
\hline Item & R Hitung & R Tabel & Keterangan \\
\hline DK1 & 0.654 & 0.204 & Valid \\
\hline DK2 & 0.778 & 0.204 & Valid \\
\hline DK3 & 0.660 & 0.204 & Valid \\
\hline DK4 & 0.753 & 0.204 & Valid \\
\hline DK5 & 0.643 & 0.204 & Valid \\
\hline DK6 & 0.520 & 0.204 & Valid \\
\hline
\end{tabular}

Dari enam pernyataan yang diuji validitasnya semua $r$ hitungnya lebih besar daripada $r$ tabel. Begitu juga dengan nilai sig.nya lebih kecil daripada 0,05. Maka semua item pernyataan pada variabel disiplin kerja valid.

Variabel Lingkungan Kerja (X2)

\begin{tabular}{lccl}
\multicolumn{4}{c}{ Tabel 6. Uji Validitas Lingkungan kerja } \\
\hline Item & R Hitung & R Tabel & Keterangan \\
\hline LK1 & 0.484 & 0.204 & Valid \\
\hline LK 2 & 0.697 & 0.204 & Valid \\
\hline LK 3 & 0.700 & 0.204 & Valid \\
\hline LK 4 & 0.786 & 0.204 & Valid \\
\hline LK 5 & 0.821 & 0.204 & Valid \\
\hline LK 6 & 0.741 & 0.204 & Valid \\
\hline LK 7 & 0.695 & 0.204 & Valid \\
\hline LK 8 & 0.548 & 0.204 & Valid \\
\hline LK 9 & 0.755 & 0.204 & Valid \\
\hline LK 10 & 0.751 & 0.204 & Valid \\
\hline
\end{tabular}


Dari sepuluh pernyataan yang diuji validitasnya semua $\mathrm{r}$ hitungnya lebih besar daripada $\mathrm{r}$ tabel. Begitu juga dengan nilai sig.nya lebih kecil daripada 0,05 . Maka semua item pernyataan pada variabel lingkungan kerja dinyatakan valid.

Variabel Kinerja Karyawan (Y)

Tabel 7. Uji Validitas Kinerja Karywan

\begin{tabular}{llll}
\hline Item & R Hitung & R Tabel & Keterangan \\
\hline KK1 & 0.698 & 0.204 & Valid \\
\hline KK2 & 0.607 & 0.204 & Valid \\
\hline KK3 & 0.758 & 0.204 & Valid \\
\hline KK4 & 0.708 & 0.204 & Valid \\
\hline KK5 & 0.772 & 0.204 & Valid \\
\hline KK6 & 0.657 & 0.204 & Valid \\
\hline
\end{tabular}

Dari enam pernyataan yang diuji validitasnya semua $r$ hitungnya lebih besar daripada $r$ tabel. Begitu juga dengan semua nilai sig.nya lebih kecil daripada 0,05. Maka semua item pernyataan pada variabel kinerja karyawan dinyatakan valid.

Uji Reliabilitas

\begin{tabular}{llll}
\multicolumn{4}{c}{ Tabel 8. Uji Reliabilitas } \\
\hline Variabel & Cronbach'Alpha & Tarap Uji & Keterangan \\
\hline $\begin{array}{l}\text { Disiplin } \\
\text { Kerja }\end{array}$ & 0.754 & 0.60 & Realibel \\
\hline $\begin{array}{l}\text { Lingkungan } \\
\text { kerja }\end{array}$ & 0.885 & 0.60 & Realibel \\
\hline $\begin{array}{l}\text { Kinerja } \\
\text { karyawan }\end{array}$ & 0.790 & 0.60 & Realibel \\
\hline
\end{tabular}

Uji reliabilitas dalam penelitian ini menggunakan nilai Cronbach's Alpha yang dibandingkan dengan angka 0,60. Jika nilai Cronbach's Alpha lebih besar daripada 0,60, maka alat ukur yang digunakan reliable. Dari semua variabel yang digunakan dalam penelitian ini yaitu variabel disiplin kerja (X1), lingkungan kerja (X2), dan kinerja karyawan (Y) nilai Cronbach's Alpha nya masingmasing adalah 0,754, 0,885, dan 0,790 semuanya lebih besar daripada 0,60. Maka alat ukur yang digunakan reliable. Artinya alat ukur yang digunakan konsisten atau stabil dari waktu ke waktu.

\section{Uji Asumsi Klasik}

Uji Normalitas

Uji ini dilakukan untuk mengetahui apakah nilai residual berdistribusi normal atau tidak. Dalam penelitian ini uji normalitas dilakukan dengan menggunakan Kolmogorov-Smirnov. Residual berdistribusi normal jika nilai sig. lebih besar daripada 0,05. Dari hasil perhitungan diperoleh nilai sig. sebesar 0,074. Karena nilai sig lebih besar daripada 0,05, maka dapat dikatakan residual berdistribusi normal.

\section{Uji Heteroskedastisitas}

Uji ini dilakukan untuk mengetahui apakah ada ketidaksamaan variance dari nilai residual dari pengamatan satu ke pengamatan yang lain. Jika variance dari nilai residual pengamatan satu ke pengamatan yang lain tetap, maka disebut homoskedastisitas. Model regresi yang baik tidak terjadi heteroskedastisitas. Uji heteroskedastisitas dalam penelitian ini menggunakan uji Glejser. Jika nilai sig. lebih besar daripada 0,05 , maka tidak terjadi heteroskedastisitas. Sebaliknya jika nilai sig. lebih kecil daripada 0,05 maka terjadi heteroskedastisitas. Dari hasil perhitungan diperoleh nilai sig 0,660 untuk variabel disiplin kerja dan nilai sig 0,318 untuk variabel lingkungan kerja. Karena nilai sig dari kedua variabel tersebut lebih besar daripada 0,05 , maka tidak terjadi heteroskedastisitas.

Uji Multikolinearitas

Uji ini dilakukan untuk mengetahui apakah ada kolerasi antar variabel bebas. Untuk mengetahui apakah ada multikolinearitas adalah dengan melihat nilai tolerance atau VIF. Jika nilai tolerance lebih besar daripada 0,10 maka tidak terjadi multikolinearitas. Atau jika nilai VIF lebih kecil daripada 10,00, maka tidak terjadi multikolinearitas.. Dari hasil perhitungan diperoleh nilai tolerance 
0,765 untuk variabel disiplin kerja dan juga 0,765 untuk variabel lingkungan kerja. Karena nilai tolerance lebih besar daripada 0,10 , maka tidak terjadi multikolinearitas. Nilai VIF yang diperoleh adalah 1,307 untuk variabel disiplin kerja dan juga 1,307 untuk variabel lingkungan kerja. Dengan cara ini juga dapat diketahui bahwa tidak terjadi multikolinearitas karena nilai VIF lebih kecil daripada 10,00 .

\section{Uji Linearitas}

Uji ini dilakukan untuk mengetahui apakah dua variabel mempunyai hubungan yang linear atau tidak. Jika nilai Deviation from Linearity Sig lebih besar daripada 0,05, maka ada hubungan yang linear. Atau jika F hitung lebih kecil daripada F tabel.

Variabel Disiplin Kerja (X1) dengan Variabel Kinerja Karyawan (Y)

Dari hasil perhitungan diperoleh nilai Deviation from Linearity Sig sebesar 0,280. Karena nilai ini lebih besar daripada 0,05 , maka dapat dikatakan ada hubungan yang linear. Atau dapat juga dilihat $\mathrm{F}$ hitungnya. Karena $\mathrm{F}$ hitung yang diperoleh sebesar 1,279 lebih kecil daripada $\mathrm{F}$ tabel yang sebesar 2,32 , maka dapat dikatakan ada hubungan yang linear.

Variabel Lingkungan Kerja (X2) dengan Variabel Kinerja Karyawan

Dari perhitungan diperoleh nilai Deviation from Linearity Sig sebesar 0,112. Karena nilai ini lebih besar daripada 0,05, maka dapat dikatakan bahwa ada hubungan yang linear. Atau dapat dilihat dari $F$ hitungnya. Karena nilai $F$ hitung yang diperoleh sebesar 1,449 lebih kecil daripada F tabel yang sebesar 2,32, maka dapat dikatakan ada hubungan yang linear.

\section{Uji Hipotesis}

Uji t

\section{Pengaruh Disiplin Kerja terhadap Kinerja Karyawan}

Analisis dengan menggunakan tingkat signifikansi 5\%:2=2,5\%=0,025 dengan derajat kebebasan $(\mathrm{df})=\mathrm{n}-\mathrm{k}-1=93-2-1=90$ di mana $\mathrm{n}$ adalah jumlah responden dan $\mathrm{k}$ adalah jumlah variabel bebas. Diperoleh t tabel 1,990.

Hasil uji t variabel disiplin kerja dapat dilihat pada tabel di bawah ini.

Tabel 9.

Coefficients $^{\mathrm{a}}$

\begin{tabular}{|c|c|c|c|c|c|}
\hline \multirow{2}{*}{ Model } & \multicolumn{3}{|r|}{$\begin{array}{l}\text { Standardized } \\
\text { Coefficients }\end{array}$} & \multirow[t]{2}{*}{$t$} & \multirow[t]{2}{*}{ Sig. } \\
\hline & $\mathrm{B}$ & Std. Error & Beta & & \\
\hline 1 (Constant) & 10,677 & 2,632 & & 4,057 & ,000 \\
\hline Disiplin Kerja (X1) & ,399 & 110 & ,355 & 3,618 &, 000 \\
\hline Lingkungan Kerja (X2) &, 129 &, 040 & ,319 & 3,254 &, 002 \\
\hline
\end{tabular}

a. Dependent Variabel: Kinerja karyawan

Sumber: Data diolah dengan SPSS 22

Dari tabel 5 di atas dapat diketahui bahwa t hitung untuk disiplin kerja adalah 3,618. Karena t hitung $(3,618)$ lebih besar daripada t tabel $(1,990)$. Atau nilai sig. $(, 000)$ lebih kecil daripada 0,05 , maka H1 diterima yaitu ada pengaruh disiplin kerja terhadap kinerja karyawan Departemen Molding PT FCC Indonesia.

Hasil penelitian ini mendukung hasil penelitian terdahulu yang dilakukan oleh Dea, at al. Artikel ketiga peneliti yang berjudul Pengaruh Disiplin Kerja dan Lingkungan Kerja terhadap Kinerja Karyawan pada PT PLN (Persero) Unit Induk Distribusi Jawa Tengah dan D.I Yogyakarta Unit Pelaksana Pelayanan Pelanggan Salatiga terbit di International Journal of Social Science and Business Vol. 4 No. 1, Februari 2020. Dalam artikel itu para peneliti menyimpulkan bahwa ada pengaruh positif disiplin kerja terhadap kinerja karyawan.

Dari tabel 5 di atas juga dapat diketahui bahwa t hitung untuk lingkungan kerja adalah 3,254. Karena thitung $(3,254)$ lebih besar daripada t tabel $(1,990)$. Atau nilai sig. $(, 002)$, lebih kecil daripada 0,005 , maka $\mathrm{H} 2$ diterima yaitu ada pengaruh lingkungan kerja terhadap kinerja karyawan Departemen Molding PT FCC Indonesia. 
Hasil penelitian ini mendukung hasil penelitian terdahulu yang dilakukan oleh oleh Hidayati at al. Artikel ketiga peneliti yang berjudul The Effect of Work Discipline and Work Environment to Performance of Employees (Case study at the Central General Hospital (RUSUP) Dr. Mohammad Hoesin Palembang) terbit di International Journal of Science and Research Publications Vol. 9 No. 12, Desember 2019. Dalam artikel itu ketiga peneliti menyimpulkan bahwa ada pengaruh positif lingkungan kerja terhadap kinerja karyawan.

Uji F

Pengaruh Disiplin Kerja dan Lingkungan Kerja secara simultan terhadap kinerja karyawan Departemen Molding PT FCC Indonesia. Analisis dengan menggunakan tingkat signifikansi 0,05 dengan df $1=$ jumlah variabel-1=3-1=2 dan df2=jumlah responden-k-1=93-2-1=90. Diperoleh $\mathrm{F}$ tabel sebesar 3,10.

Hasil uji F dapat dilihat pada tabel di bawah ini.

Tabel 10.

Anova $^{\mathrm{a}}$

\begin{tabular}{|c|c|c|c|c|c|}
\hline Model & $\begin{array}{l}\text { Sum of } \\
\text { Squares }\end{array}$ & Df & Mean Square & $\mathrm{F}$ & Sig. \\
\hline 1 & 164,178 & 2 & 82,089 & 22,920 &, $000^{\mathrm{b}}$ \\
\hline Regression & 322,338 & 90 & 3,582 & & \\
\hline Residual & 486,516 & 92 & & & \\
\hline
\end{tabular}

a. Dependent Variabel: Kinerja Karyawan

b. Predictors: (Constant), Disiplin Kerja (X1), Lingkungan Kerja (X2)

Sumber: Data diolah dengan SPSS 22

Dari tabel 6 di atas dapat diketahui F hitung adalah 22,920. Karena F hitung $(22,920)$ lebih besar daripada $\mathrm{F}$ tabel $(3,10)$ atau nilai sig. lebih kecil daripada 0,05 , maka $\mathrm{H} 3$ diterima yaitu ada pengaruh disiplin kerja dan lingkungan kerja secara simultan terhadap kinerja karyawan Departemen Molding PT FCC Indonesia.

Hasil penelitian ini mendukung hasil penelitian terdahulu yang dilakukan oleh Sarwani. Artikel peneliti yang berjudul "The effect work discipline and work environment on the performance of employees" terbit di jurnal SINERGI Vol. 6 No. 2, September 2016. Dalam artikelnya peneliti menyimpulan bahwa ada pengaruh secara simultan disiplin kerja dan lingkungan kerja terhadap kinerja karyawan.

Analisis Koefisien Determinasi

Tabel 11.

Model Summary

\begin{tabular}{|c|c|c|c|c|}
\hline Model & $\mathrm{R}$ & R Square & $\begin{array}{l}\text { Adjusted } \\
\text { R Square }\end{array}$ & $\begin{array}{l}\text { Std. Error of the } \\
\text { Estimate }\end{array}$ \\
\hline 1 &, $581^{a}$ & ,337 & ,323 & 1,892 \\
\hline
\end{tabular}

a. Predictors: (Constant), Disiplin Kerja (X1), Lingkungan Kerja (X2)

Sumber: Data yang diolah dengan SPSS 22

Dari tabel 7 di atas dapat diketahui besarnya R Square adalah 0,337 (33,7\%). Ini berarti persentase sumbangan pengaruh disiplin kerja dan lingkungan kerja terhadap kinerja karyawan adalah sebesar $33,7 \%$. Sedangkan sisanya yang $66,3 \%$ dipengaruhi oleh variabel-variabel lain yang tidak diteliti dalam penelitian ini.

Persamaan Regresi Linear Berganda

Dalam penelitian ini persamaan regresi linear berganda dapa ditulis sebagai berikut:

$$
\begin{aligned}
& \mathrm{Y}=\mathrm{a}+\mathrm{b} 1(\mathrm{X} 1)+\mathrm{b} 2(\mathrm{X} 2)+\mathrm{e} \\
& \mathrm{Y}=10,677+0,399(\mathrm{X} 1)+0,129(\mathrm{X} 2)+\mathrm{e}
\end{aligned}
$$


1. Nilai konstanta sebesar 10,677 tidak diinterpretasikan karena angka terkecil pada skala Likert adalah satu. Tidak ada angka nol pada skala Likert.

2. Koefisien regresi disiplin kerja (X1) sebesar 0, 399 artinya jika disiplin kerja ditingkatkan, maka kinerja karyawan (Y) akan meningkat karena angka itu angka positif dengan asumsi lingkungan kerja (X2) konstan.

3. Koefisien regresi lingkungan kerja (X2) sebesar 0,129 artinya jika disiplin kerja ditingkatkan, maka kinerja karyawan (Y) akan meningkat karena angka itu angka positif dengan asumsi dsiplin kerja (X1) konstan.

\section{PEMBAHASAN}

Dari hasil penelitian ini dapat diketahui bahwa ada pengaruh disiplin kerja terhadap kinerja karyawan dan pengaruhnya bersifat positif karena ditunjukkan dengan angka positif sebesar 0,399. Ini artinya jika perusahaan meningkatkan disiplin kerja karyawannya, maka kinerja karyawan akan meningkat. Ini karena karyawan yang memiliki disiplin kerja akan selalu teratur dalam bekerja. Ia akan memelihara kehadirannya dengan baik, datang tepat pada waktunya, pulang pada waktu jam pulang kantor telah tiba, mengikuti prosedur kerja yang telah ditetapkan, dan semua aturan yang dibuat oleh perusahaan untuk memelihara keteraturan. Perusahaan memerlukan keteraturan-keteraturan dalam usahanya untuk mencapai tujuan.

Dari hasil penelitian ini juga dapat diketahui bahwa ada pengaruh lingkungan kerja terhadap kinerja karyawan dan pengaruhnya bersifat positif karena ditunjukkan dengan angka positif sebesar 0,129 . Angka ini berarti bahwa jika perusahaan meningkatkan kondisi atau lingkungan kerjanya menjadi lebih baik seperti misalnya penerangan di tempat kerja yang cukup, temperatur yang sesuai untuk tubuh para karyawan, keamanan di lingkungan kerja yang terjaga baik, maka kinerja karyawan akan meningkat.

Dari hasil penelitian ini dapat diketahui bahwa ada pengaruh secara simultan disiplin kerja dan lingungan kerja terhadap kinerja karyawan. Ini artinya jika disiplin kerja diterapkan secara benar sehingga tercipta kondisi di mana para karyawan bersedia bekerja sama dan bersamaan dengan itu juga lingkungan kerja diciptakan sedemikian rupa sehingga dapat memacu semangat dan gairah para karywan, maka kinerja karyawan akan meningkatkan. Dari hasil penelitian ini juga dapat diketahui angka $0,337(33,7 \%)$. Angka ini menunjukkan persentase sumbangan pengaruh disiplin kerja dan lingkungan kerja terhadap kinerja karyawan.

\section{KESIMPULAN}

Berdasarkan hasil yang telah diutarakan sebelumnya, ada tiga hal yang dapat disimpulkan, yaitu: Disiplin kerja berpengaruh positif terhadap kinerja karyawan. Hal ini dapat diketahui dari uji yang telah dilakukan yang menghasilkan angka koefisien regresi yang positif. Lingkungan kerja berpengaruh positif terhadap kinerja karyawan. Hal ini dapat diketahui dari uji yang telah dilakukan yang menghasilkan angka koefisien regresi yang positif. Secara simultan motivasi kerja dan disiplin kerja berpengaruh terhadap kinerja karyawan.

\section{IMPLIKASI}

Disiplin kerja yang sebelumnya diduga berpengaruh terhadap kinerja karyawan, ternyata dalam penelitian ini memang disiplin kerja berpengaruh terhadap kinerja karyawan dan pengaruhnya positif. Ini dapat membuat perusahaan untuk terus meningkatkan disiplin kerja karyawan. Lingkungan kerja yang sebelumnya diduga berpengaruh terhadap kinerja karyawan, ternyata dalam penelitian ini memang lingkungan kerja berpengaruh terhadap kinerja karyawan dan pengaruhnya positif. Ini dapat membuat perusahaan untuk terus meningkatkan lingkungan kerja.

\section{REFERENSI}

Busro, M. 2020. Teori-Teori Manajemen Sumber Daya Manusia. Edisi Pertama. Prenadamedia Group. Jakarta.

Dea, G., O. Sundari., dan J. Dongoran. 2020. Pengaruh Disiplin Kerja dan Lingkungan Kerja terhadap Kinerja Karyawan pada PT PLN (Persero) Unit Induk Distribusi Jawa Tengah dan D.I Yogyakarta Unit Pelaksana Pelayanan Pelanggan Salatiga. International Journal of Social Science and Business Ekonomi dan Kewirausahaan, 4 (1), 144-154. P-ISSN: 2614-6533. EISSN: 2549-6409. https://ejournal.undiksha.ac,id. 
Farisi, S. dan W. M. Fani. 2019. Influence of Work Environment and Work Discipline on Employee Performance. International Conference on Global Education VII "Humanizing Technology for IR. 4.0.” Padang Panjang 1-2 Juli: 69-81. P-ISBN: 978-602-53692-5-4. E-ISBN: 978-60253692-6-1. https://ejurnal.unespadang.ac,id >article>view.

Ferawati, A. 2017. Pengaruh Lingkungan Kerja dan Disiplin Kerja terhadap Kinerja Karyawan. AGORA, 5(1), https://publication.petra.ac.id>download.

Hamali, A. Y. 2018. Pemahaman Manajemen Sumber Daya Manusia: Strategi Mengelola Karyawan. CAPS (Center for Academic Publishing Service). Yoyakarta.

Handayani, R. 2019. The Effect of Discipline and Work Environment on Employee Performance. PINISI Discretion Review, 2(2), 125-134. https://researchgate.net>publication>34.

Hasibuan, M. S. P. 2009. Manajemen Sumber Daya Manusia. Edisi revisi. PT Bumi Aksara. Jakarta.

Hidayati, S.K., B. Perizade, dan M. Widiyanti. 2019. Effect of Work Discipline and Work Environmen to Performance of Employees. International Journal of Scientific and Research Publications, 9(12), 392-398. ISSN 2250-3153. https://researchgate.net $>$ publication $>33$. Doi: 10.29322/IJSRP.9.12.2019. p9643.

Liestiani, N. L., Perizade, B., \& Agustina Hanafi, Z. (2019). The Effect of Work Discipline and Work Environment on the Performance of AL Hudori Cooperative of Palembang Employees. Journal of Economics and Business, 2(1), 61-72.

Mangkunegara, A. A. A. P. 2017. Manajemen Sumber Daya Manusia Perusahaan. PT Remaja Rosdakarya. Bandung.

Nitisemito, A. S. 2018. Manajemen Personalia. Ghalia Indonesia. Jakarta.

Polakitan, R., G. M. Sendow, dan G. G. Lumintang. 2016. Pengaruh Kepemimpinan, Kompensasi dan Lingkungan Kerja terhadap Kinerja Karyawan PT Asuransi Wahana Tata Manado. Jurnal EMBA, 4(3), 1068-1077. ISSN 2303-1174. https://ejournal.unsrat.ac.id>download.

Sarwani. 2016. The Effect of Work Discipline and Work Environment on Performance of Emploees. Jurnal SINERGI, 6(2), 53-66. https://ejournal.unitomo.ac.id>article>view

Siagian, S.P. 2018. Manajemen Sumber Daya Manusia. PT Bumi Aksara. Jakarta.

Sinambela, L. P. 2018. Manajemen Sumber Daya Manusia: Membangun Tim Kerja Yang Solid untuk Meningkatkan Kinerja. Jakarta: PT Bumi Aksara. Jakarta.

Sutrisno, E. 2017. Manajemen Sumber Daya Manusia. Prenadamedia Group. Jakarta.

Tanujaya, L. R. (2015). Pengaruh pelatihan kerja dan motivasi kerja pada kinerja karyawan departemen produksi PT Coronet Crown. Agora, 3 (1), 1-7. http://media.neliti.com>publications $>3$. 